purpose of formation of poly-gram student literacy.

One of the main values of the future teacher is creative activity, and, accordingly, an effective method of forming research skills among students - future teachers of a foreign language, in our opinion, is the rational use of elements of problem-search training in all forms of university educational work: lectures, seminars, practical training, teaching practice, term papers and dissertations, etc. O ne of the conditions for the formation of research skills of future teachers of foreign languages $s$ is the presence of subject-subject interaction. This condition requires posing the problem in an accessible form.

Therefore, in order to develop the ability of a future teacher of a foreign language to introduce research skills into the learning process, it is necessary to update not only the content of curricula in all disciplines, but also the teaching methods; persistently introduce the discussion form of practical training into the educational process; provide for students an independent search for causal relationships and patterns of social processes and phenomena; hold creati ve contests of student work.

Keywords: research skills, problem learning, problem, problem, future teacher, creative activity, methods, forms, methods.

DOI: https://doi.org/10.31392/NZ-npu-142.2019.04

УДК 373.5.091.26:51(477)"2008/2018"

Биковський Я. Т.

\title{
ПОРІВНЯЛЬНИЙ АНАЛІЗ СУЧАСНОГО СТАНУ ОСВІТНІХ РЕЗУЛЬТАТІВ УЧНІВ 3 ФІЗИКИ І МАТЕМАТИКИ: 2008-2018 РОКИ
}

У статті увага зосереджена на питанні оцінювання якості освіти. Представлено порівняльний аналіз сучасного рівня освітніх результатів учнів з фізики і математики у період з 2008 р. по 2018 р. за результатами зовнішнього незалежного оиінювання (3НО).

Особлива увага приділяється аналізу змін та корелячії даних результатів в охопленні учасників тестування з фізики і математики; динаміки середнього балу; відсотку учасників тестування, які складають тест з фізики і математики на 190 і більше балів, а також тих, які його не складають.

Порівняльний аналіз даних свідчить, щэо за 10 років відбувається сильна тенденція до зменшення кількості учасників тестування як з фізики, так $i$ з математики. Також відбувається значне збільшення відсотку тих учасників, які не проходять тест 3 нО з фізики та математики. Крім иьього, збільшується відсоток робіт, які виконані дуже добре (понад 190 балів), але водночас середній бал не має чітких позитивних чи негативних тенденцій з фізики чи математики.

Важливими і тривожними є показники відсотку учасників ЗНО, що не проходять тестування з фізики і математики. Так, останні 3 роки є найгіршими як для математики, так і для фізики за цим показником, який зріс приблизно в 2 рази.

Виявлено, що учасники ЗНО з фізики та математики, в останні роки сильніме розшаровуються на дві групи: на тих, щуо знають матеріал дуже добре, i на тих, хто його знає погано.

Відповідно з таких даних можна зробити висновок про необхідність посилення уваги до навчання учнів з фізики і математики у закладах освіти.

Ключові слова: якість освіти, рівень знань, фізика, математика, зовнішне незалежне оиінювання (ЗНО), аналіз даних. 
У сучасних умовах реформування освіти важливим постає питання якості освіти, якості освітньої діяльності. Ці питання в Україні та світі зосереджені як у нормативно-правових документах, так і працях вчених.

Закон України “Про освіту" встановлює, що: "Якість освіти - відповідність результатів навчання вимогам, встановленим законодавством, відповідним стандартом освіти та/або договором про надання освітніх послуг" [11]. При цьому, "Якість освітньої діяльності - рівень організації, забезпечення та реалізації освітнього процесу, що забезпечує здобуття особами якісної освіти та відповідає вимогам, встановленим законодавством та/або договором про надання освітніх послуг" [11].

Великий енциклопедичний словник визначає, що: “Якість - фрілософська категорія, що виражає істотну визначеність об'єкта, завдяки якій він є саме цим, а не іншим. Якість - об'єктивна і загальна характеристика об'єктів, що виявляється в сукупності властивостей" [12].

У Філософському словнику вказано, що "якість відображає важливі сторони об'єктивної дійсності. Як би не змінювався предмет, але до певного часу він залишається саме собою, і не чим іншим, якісно визначеним предметом".

Питанню якості освіти присвячені праці таких вчені, як: І. Є. Булах [14], В. Г. Вікторов [15], Л. Г. Логінова [16], Т. О. Лукіна [17], М. М. Поташнік [18] тощо.

Встановлено, що велика увага у питанні якості освіти, якості освітньої діяльності приділяється фрормам оцінювання і показникам.

Міністерство освіти і науки України встановлює, що: "Якість освіти комплекс характеристик освітнього процесу, що визначають послідовне та практично ефективне фрормування компетентності та професійної свідомості. Це певний рівень знань і вмінь, розумового, фрізичного й морального розвитку, якого досягли випускники освітнього закладу відповідно до запланованих цілей навчання і виховання.

Формами оцінювання якості освіти в повній загальній середній освіті Міністерство освіти і науки України встановлює:

Зовнішнє незалежне оцінювання (ЗНО);

Державна підсумкова атестація (ДПА);

PISA (Програма міжнародного оцінювання учнів)" [19].

Визначено, що зовнішнє незалежне оцінювання (ЗНО) $€$ "комплекс організаційних процедур (передусім - тестування) спрямований на визначення рівня навчальних досягнень випускників середніх навчальних закладів при їхньому вступі до закладів вищої освіти" [20].

ЗНО, як форма оцінювання якості освіти, відображає сучасний стан знань учнів України та динаміку їх змін.

На прикладі зовнішнього незалежного оцінювання (далі 3НО) проведемо порівняльний аналіз сучасного стану освітніх результатів учнів з фрізики і математики за останні 10 років.

Отже, метою cmammi $€$ порівняльний аналіз основних показників зовнішнього незалежного оцінювання (ЗНО) при тестуванні 3 фрізики та математики протягом 2008-2018 pp. Особливу увагу приділимо таким показникам фформи оцінювання якості освіти з фрізики та математики, як: 
1) охоплення учасників тестування; 2) динаміка середнього балу; 3) відсоток учасників тестування, які складають тест на 190 і більше балів; 4) відсоток учасників тестування, які не складають $3 \mathrm{HO}$.

Перш за все, відповідно до матеріалів Українського центру оцінювання якості освіти (далі УЦОЯО) проаналізуємо дані щодо математики.

Встановлено, що впродовж 2008-2018рр. кількість учасників 3НО 3 математики суттєво зменшилась. Так, кількість учасників 3 НО з математики у 2008 р. становила близько чверті мільйона учасників тестування (226 084) [1], а у 2018 р. - 106483 [2]. При цьому, протягом цих років спостерігається нерівномірна динаміка, а саме: 2009 р. - 235305 [3] учасників тестування, 2010 p. - 110759 [4], 2011 p. - 145510 [5], 2012 p. - 94366 [6], 2013 p. - 90343 [7], 2014 p. - 147036 [8], 2016 p. - 123047 [9], 2017 p. - 106325 [10] (рис. 1).

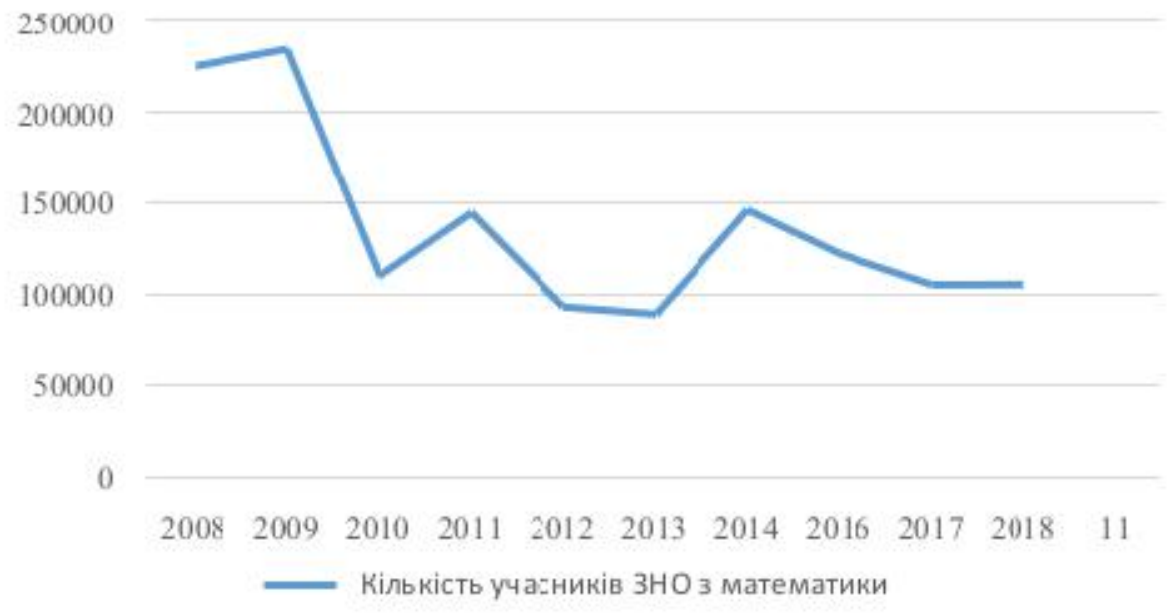

Рис. 1. Кількість учасників ЗНО з математики за роками, 2008-2018 рр.

Таким чином, наведені дані дають можливість стверджувати, що за 10 років кількість учасників тестування з математики зменшилась у понад два рази. Дана ситуація зумовлена суб'єктивними та об'єктивними причинами. Серед них вагому роль відіграло зменшення кількості учнів внаслідок "демографічної кризи", що почалася в 1990-х рр., проявилася в істотному зменшенні народжуваності і, як результат, кількості учасників тестування.

Слід відзначити, що динаміка середнього балу, відсотку учасників тестування, які складають тест на 190 і більше балів і тих, хто його не здають, має нерівномірну динаміку.

Аналіз ситуації показує, що впродовж 2008-2018 рр. середній бал учасників тестування 3 математики має стрибкоподібну характеристику 3 позитивними тенденціями до збільшення.

Так, за даними Українського центру оцінювання якості освіти середній бал 3 НО з математики у 2008 р. становив 20\% від максимально можливого [1], 2018 p. - 37,5\% [2].

Слід відмітити, що серед учнів середній бал $3 \mathrm{HO} з$ математики постійно зростав з незначним зменшенням в окремих роках: 2009 р. - 25,7\% [3], 2010 р. - 36\% [4], 2011 p. - 31\% [5], 2012 p. - 39\% [6], 2013 p. - 34\% [7], 2014 p. - 28,6\% [8], 2016 p. - 33,8\% [9], 2017 p. - 39,2\% [10], 2018 p. - 37,5\% [2]. 
Отже, протягом 10 років відбулися позитивні зміни в результатах тестування учасників ЗНО з математики щодо середнього балу, який зріс у 1,5 рази у 2018 р. порівняно з 2008 р.

Водночас аналіз ситуації щодо учасників ЗНО, які не склали тест 3 математики, показав, що впродовж 2008-2018 рр. відбулися суттєві найбільші зміни в сторону погіршення ситуації.

За даними Українського центру оцінювання якості освіти у 2008 р., відсоток учасників тестування, які не склали тест з математики, становив 4,6\% від їх загальної кількості [1], 2009 р. - 9,6\% [3], 2010 р. - 7,2\% [4], 2011 р. 7,2\%[5], 2012 p. - 9,3\% [6], 2013 p. - 7,3\% [7], 2014 p. - 6,7\% [8], 2016 p. - 12,7\% [9], 2017 p. - 14\% [10], 2018 p. - 15\% [2].

Так, у 2008 р. відсоток учасників тестування, які не склали тест ЗНО, був найнижчим показником за 10 всі роки. У наступному, 2009 р., відсоток тих, хто не склав тестування з математики збільшилася у понад 2 рази і становив 9,6\% від загальної кількості учасників тестування.

Надалі відсоток, що не складає ЗНО з математики поступово знижується до локального мінімуму в 6,7\% в 2014 р.

Однак після 2014 р. відсоток почав збільшуватися і у 2016 р. досяг позначки 12,7\% серед учасників тестування, які його не склали тестування 3 математики від їх загальної кількості.

Надалі негативна тенденція продовжилася всі наступні роки, тобто відсоток учасників ЗНО, які не складають тестування з математики зростає в 2015-2018 рр. і становить у 2018 р. - 15\%, що є найгірший показник за 10 років.

Таким чином, впродовж 2008-2018рр. відсоток учасників, які не склали тестування з математики суттєво змінювалося. Розпочався з мінімального 4,6\% у 2008 р., мав середні значення в 2007-2014 рр. і набуває найгірших значень у 2016-2018 рр. Відсоток учасників 3НО, що не складає тест з математики у 2018 р. підвищився у 3 рази в порівнянні з 2008 р.

Аналізуючи ситуацію щодо учасників тестування 3 математики, які складають ЗНО на 190 і більше балів упродовж 2008-2018рр., варто відмітити незначні зміни, але з позитивною динамікою.

За даними Українського центру оцінювання якості освіти у 2008 р. цей показник становив 2,1\% учасників тестування від їх загальної кількості [1], 2009 p. - 2,2\% [3], 2010 p. - 2,4\% [4], 2011 p. - 2\% [5], 2012 p. - 2,2\% [6], 2013 p. - 2,2\% [7], 2014 p. - 2,3\% [8], 2016 p. - 1,8\% [9], 2017 p. - 3\% [10], 2018 p. $3,2 \%[2]$.

Узагальнені дані щодо рівня освітніх результатів учнів з математики, зокрема динаміка середнього балу, відсоток учасників тестування, які складають тест на 190 і більше балів і тих, хто його не здають протягом 20082018 рр., представимо на діаграмі (рис. 2).

Загальний висновок щодо аналізу результатів 3НО з математики в 20082018 рр. можна зробити наступний.

Поряд із збільшенням відсотка учасників тестування, які складають ЗНО на понад 190 балів і більше, $є$ значне, у понад три рази, збільшення відсотка учасників ЗНО з математики, які зовсім не складають його.

При цьому середній рівень знань учасників тестування знаходиться в межах від 20\% до 37,5\%. 
Таким чином, впродовж 2008-2018 рр. спостерігається розподіл учасників тестування на 2 групи: тих, які складають ЗНО вище середнього і тих, які не можуть взагалі його скласти.

По-друге, відповідно до матеріалів Українського центру оцінювання якості освіти проаналізуємо дані щодо фрізики.

Встановлено, що з 2008 р. по 2018 р. відбулось суттєве зменшення кількості учасників $3 \mathrm{HO}$ з фрізики.

Так, аналіз ситуації показує, що у 2008 р. кількість учасників тестування ЗНО з фрізики становила 32592 [1], у 2018 р. - 20836 [2].

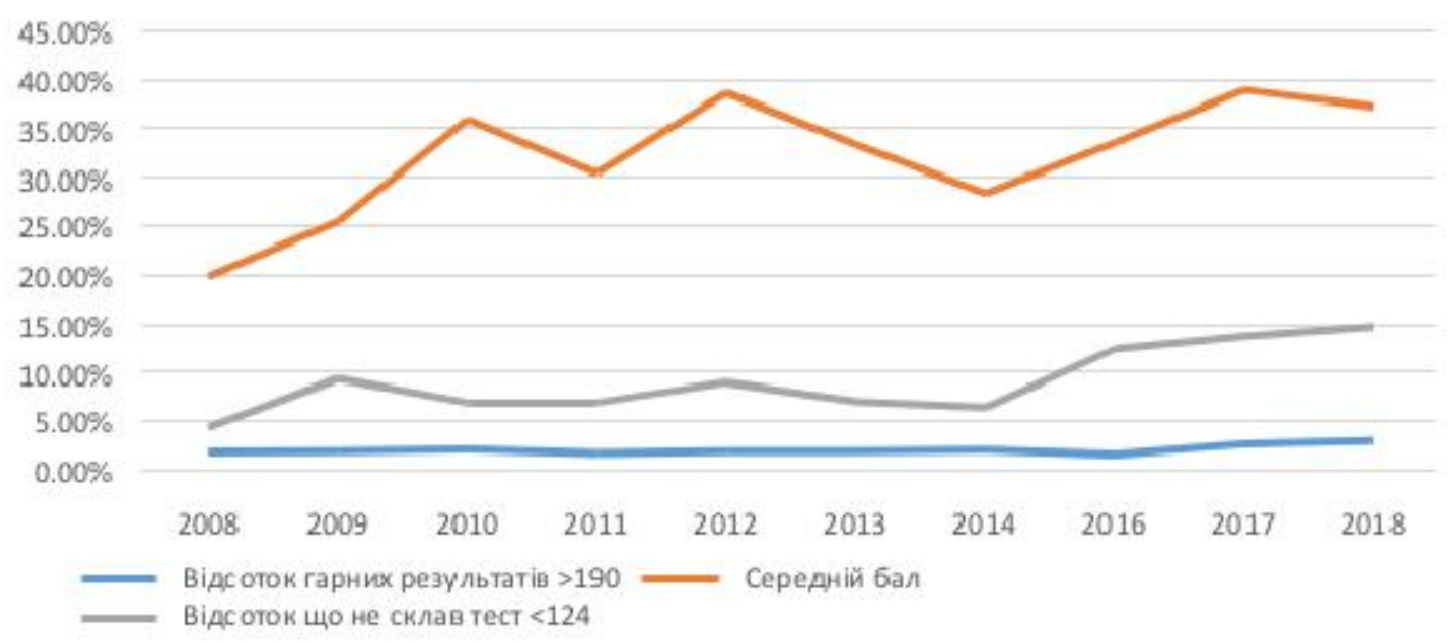

Рис. 2. Рівень освітніх результатів учнів з математики на прикладі ЗНО за роками, 2008-2018 рр.

При цьому, протягом цих років при тестуванні $3 \mathrm{HO}$ з фрізики спостерігається нерівномірна динаміка участі, а саме: 2009 р. - 32142 [3] учасника тестування, 2010 р. - 46439 [4], 2011 р. - 46240 [5], 2012 р. - 46240 [6], 2013 p. - 61403 [7], 2014 p. - 53202 [8], 2016 p. - 27771 [9], 2017 p. 23597 [10] (рис. 1).

Детальний аналіз даних показує, що починаючи з 2010 р. і до 2013 р., показник учасників тестування $3 \mathrm{HO}$ з фізики збільшився майже вдвічі, а після 2013 р. кількість учасників 3НО з фізики суттєво падає вниз і знаходить свій мінімум в 2018 р. Отже, впродовж 2008-2018 рр. кількість учасників тестування з фрізики зменшилась у 1,5 рази (рис. 3.)

Більш детально проаналізуємо динаміку середнього балу, відсоток учасників тестування, які складають тест на 190 і більше балів та відсоток учасників тестування, які не складають ЗНО з фрізики за даними Українського центру оцінювання якості освіти.

Аналіз даних середнього балу ЗНО з фрізики показує, що у період з 2008 p. до 2018 р. є певні коливання щодо участі учнів з тенденцією до зменшення. Так, 2008 p. - 35,8\% [1], 2009 p. - 26,5\% [3], 2010 p. - 33,0\% [4], 2011 p. - 29,8\% [5], 2012 p. $-32,0 \%$ [6], 2013 p. - 31,2\% [7], 2014 p. - 27,52\% [8], 2016 p. - 33,9\% [9], 2017 p. - 30,0\% [10], 2018 p. - 36,7\% [2]. 


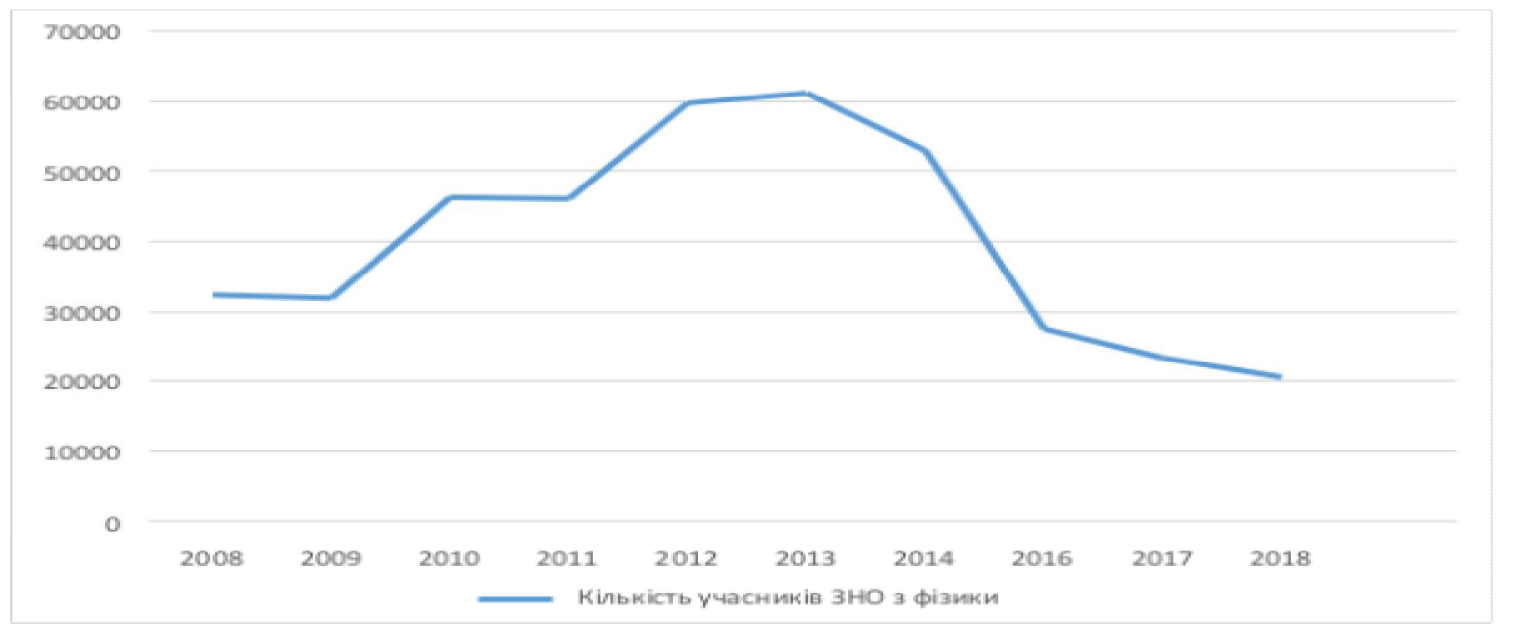

Рис. 3. Кількість учасників ЗНО з фізики за роками, 2008-2018 рр.

Так, з 2008 р. по 2017 р. серед учнів показники середнього балу ЗНО 3 фрізики мають нерівномірну динаміку. Водночас, якщо у 2008 р. показник середнього балу 3 НО з фізики мало 35,8\% осіб, у 2014 р. - 27,5\%, то у 2018 р. він трохи покращився до рівня $36,7 \%$.

Аналіз результатів кількості учасників, які не складають 3НО з фізики за даними Українського центру оцінювання якості освіти свідчить про негативну тенденцію.

Встановлено, що за останні 3 роки відсоток учнів, які не пройшли тест $3 \mathrm{HO}$ з фрізики $є$ найгіршим за всі 10 років.

Так, якщо у 2008 р. відсоток учнів, які не подолали поріг ЗНО з фрізики становив 9,7\% [1], то у наступних роках відповідно: 2009 р. - 6,6\% [3], 2010 р. 6,9\% [4], 2011 p. - 6,9\% [5], 2012 p. - 9,1\% [6], 2013 p. - 8,1\% [7], 2014 p. - 6,0\% [8], 2016 p. - 14,3\% [9], 2017 p. - 19,8\% [10], 2018 p. - 13,7\% [2].

Аналізуючи дані освітніх результатів учнів з фрізики на прикладі $3 \mathrm{HO}$, можна помітити, що після 2014 р. надзвичайно збільшилась кількість учнів, які не подолали тест ЗНО з фізики. А саме з 6,07\% у 2014 р. до максимальних $19,82 \%$ у 2017 р. Наразі тест ЗНО з фрізики не склали $13,7 \%$, що є кращим показником за 2016-2018 рр., але гіршим за 2014 р., в якому тест не склали $6,0 \%$.

Тенденція зміни відсотку учасників тестування, що склали ЗНО гарно не особливо варіювалася впродовж 10 років. Однак, у 2018 р. маємо позитивне підвищення в 2 рази порівняно з 2017 р.

Так, відсоток учасників тестування ЗНО з фрізики, що мали результати вище за 190 балів, у 2008 р. становила 2,4\% [1], 2009 р. - 2,8\% [3], 2010 р. 2,2\% [4], 2011 p. - 2,2\% [5], 2012 p. - 2,3\% [6], 2013 p. - 2,1\% [7], 2014 p. - 2,1\% [8], 2016 p. - 1,9\% [9], 2017 p. - 1,8\% [10], 2018 p. - 3,6\% [2].

Отже, на основі аналізу результатів учасників, що складали 3НО з фізики 3 2008 р. по 2018 р., можна констатувати наступне.

Кількість учасників 3НО з фізики починаючи з 2013 р. зменшується і наразі $\epsilon$ мінімальною за весь час проведення 3 НО. Також останні 3 роки $є$ найгіршим показник відсотку учнів, які не складають тест $3 \mathrm{HO}$ з фізики. Він виріс у 2 рази в порівнянні з 2009-2011 pр. та 2014 р. та майже у 1,5 рази в порівнянні з 2008 р. 


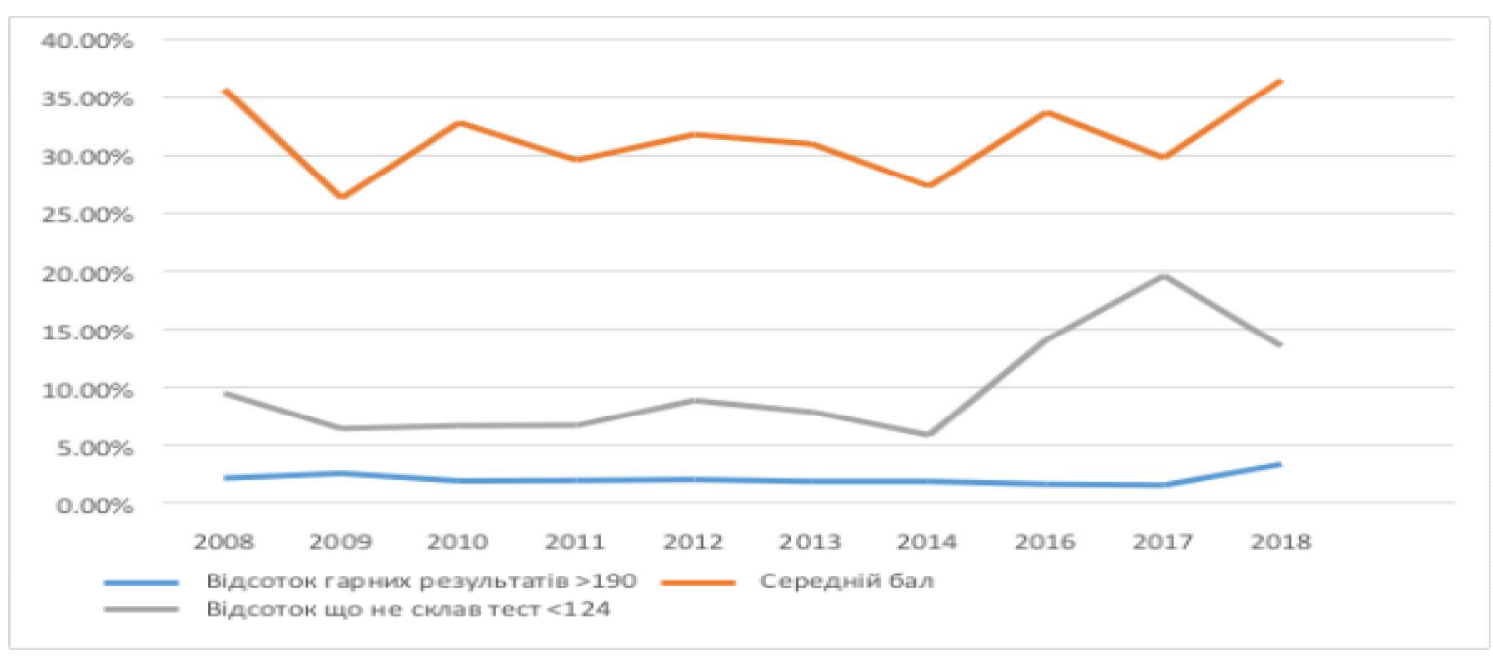

Рис. 4. Рівень освітніх результатів учнів з фізики на прикладі $3 Н О$ за роками, 2008-2018 рр.

У той же, час середній бал ЗНО з фрізики тримається на досить високому рівні і в 2018 р. набуває свого максимум в 36, 7\%.

Важливо також відмітити позитивний стрибок у 2 рази відсотка учнів, які склали ЗНО з фрізики на відмінно у 2018 р. Тобто можна стверджувати, що учасники сильніше розмежовуються на дві підгрупи: ті, що знають фрізику добре і тих, хто знає фрізику погано.

По-третє, зробимо порівняльний аналіз сучасного стану рівня освітніх результатів учнів з фрізики і математики протягом 2008-2018 рр.

Як зазначалося вище, кількість учасників тестування, що складали тест ЗНО з фрізики зростає з 32592 учасників у 2008 р. до 61403 учасників у 2013 р., а кількість учнів, що складали тест ЗНО з математики в той же період, зменшується з 226084 учнів у 2008 р. до 90343 учасників тестування у 2013 р. Після 2013 р. ситуація змінюється і кількість учасників тестування з математики зростає до 106483 у 2018 р., а з фрізики навпаки, падає до 20836 учасників.

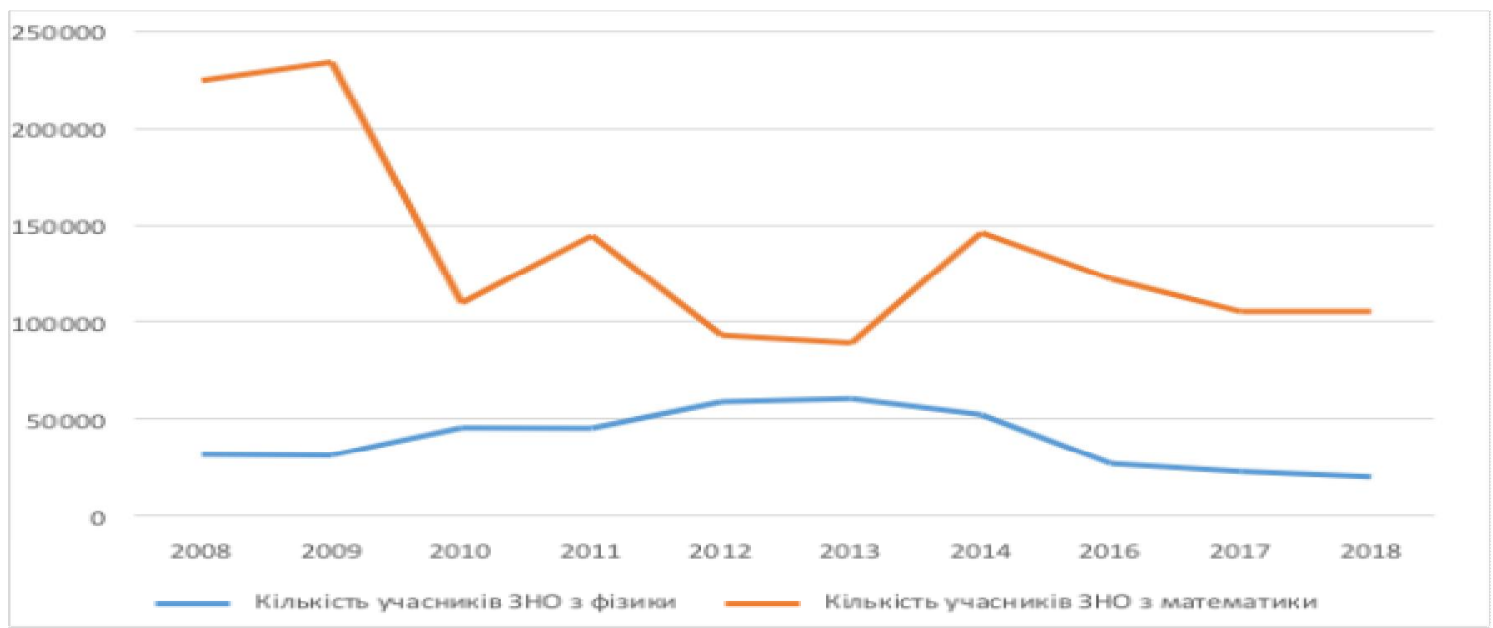

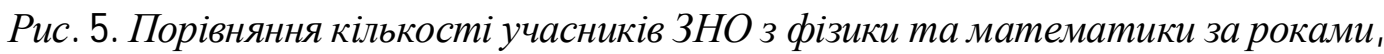
2008-2018 pp. 
Отже, кількість учасників тестування, які здають ЗНО з фрізики порівняно 3 математикою менша в 5 разів. При цьому, кількість учасників тестування 3 фрізики зазнавала не таких сильних змін упродовж останніх 10 років, як у математиці.

Порівняння середнього балу у відсотках до максимального учасників тестування $3 \mathrm{HO}$ з фрізики та математики показали різну динаміку. Так, у 2008 р. середній бал у відсотках до максимального учасників тестування 3НО з математики фрізики був мінімальний, тоді як для фрізики один з кращих років.

Хоча показник середнього балу з фрізики та математики почалися з істотно різних позицій в 35,9\% для фрізики та 20,1\% для математики в 2008 р. та істотно змінювалися впродовж років, але в 2018 р. майже зрівнялися на позначках 37,5\% з математики та $36,7 \%$ з фрізики.

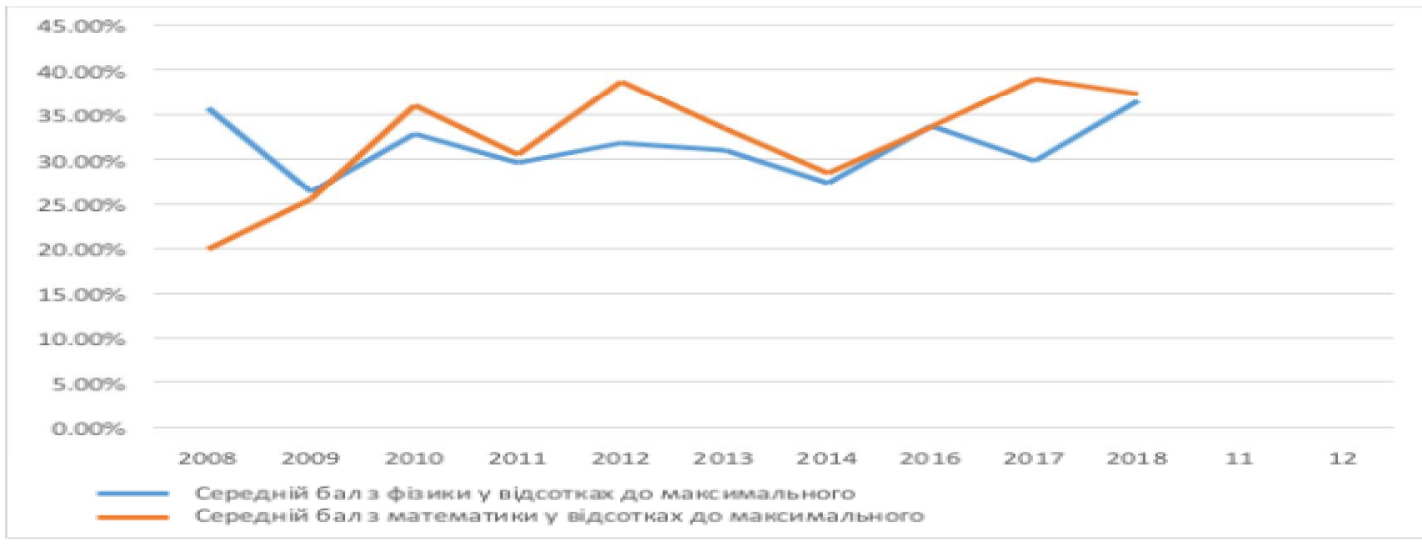

Рис. 6. Порівняння середнього балу з фізики та математики учасників ЗНО за роками, 2008-2018 рр.

Порівняльний аналіз учасників, які не склали тест ЗНО з фрізики та математики свідчить про їх збільшення.

Особливу увагу треба звернути на останні 3 роки, де є тенденцією суттєве збільшення відсотку тих, хто не склав ЗНО як з математики, так і фрізики й відповідно $є$ негативним показником за весь час проведення ЗНО.

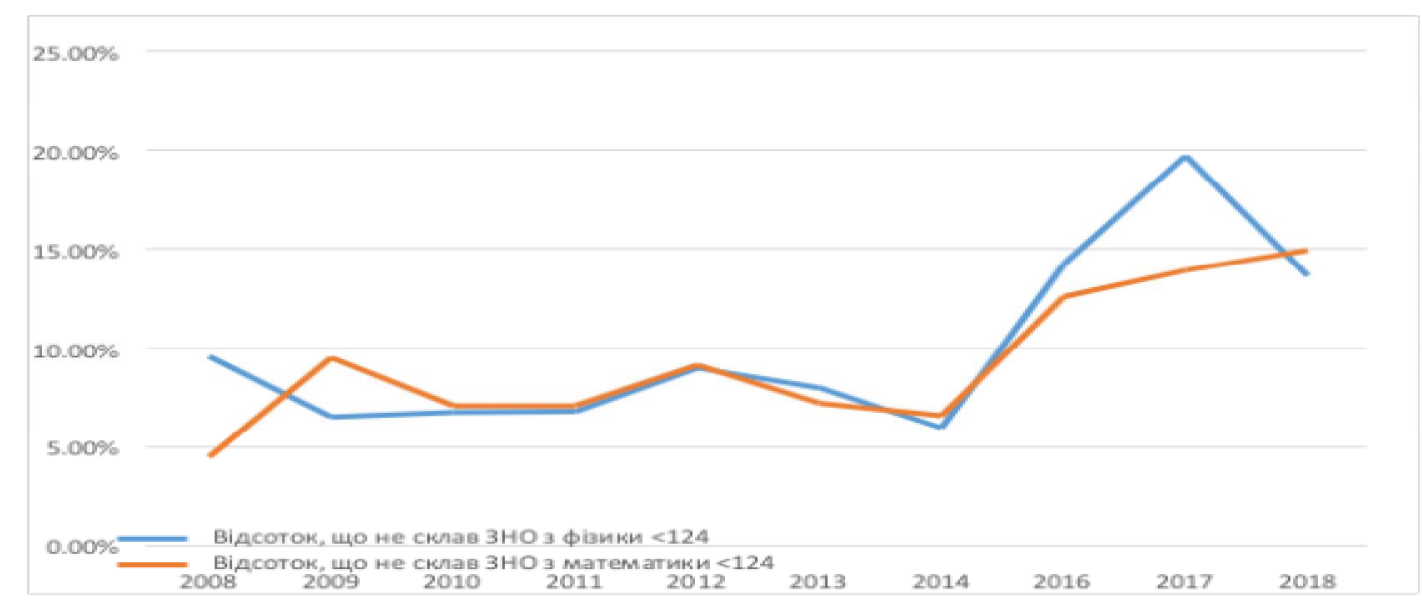

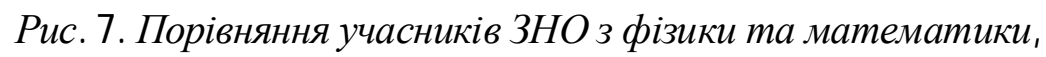
які не склали, за роками, 2008-2018 рр. 
Аналіз учасників тестування, які склали ЗНО з фрізики та математики на оцінку понад 190 балів свідчить про нерівномірну динаміку з високим показником за останній рік. Так, у 2018 р. відсоток учасників 3НО, які склади тест на 190 балів і вище збільшився у 1,5 рази як 3 фізики (2009 р. - 2,4\%, 2018 р. - 3,6\%), так і з математики (2008 р. - 2,1\%, 2008 р. - 3,2\%).

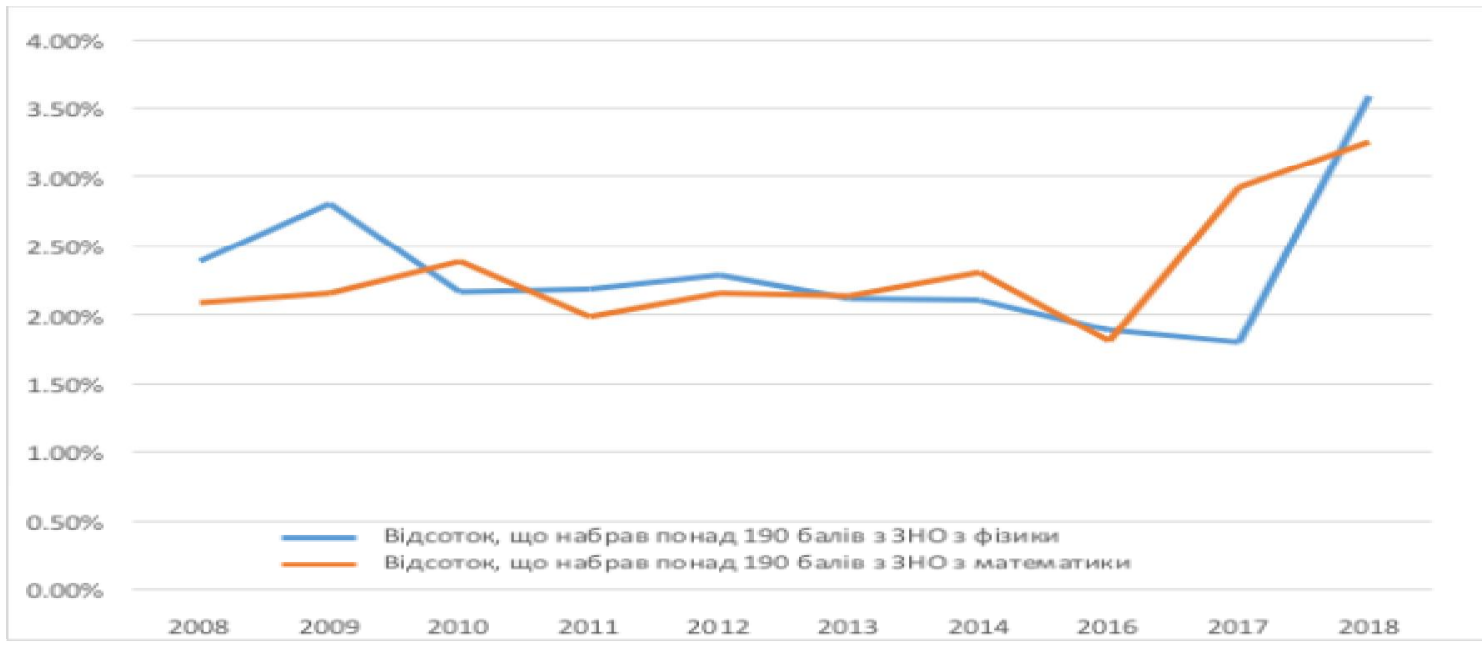

Рис. 8. Порівняння учасників $3 Н О$ з фізики та математики, які склали на 190 і більше балів, за роками, 2008-2018 рр.

Отже, порівняльний аналіз даних свідчить, що за 10 років відбувається сильна тенденція до зменшення кількості учасників тестування як з фізики, так i з математики. Також відбувається значне збільшення відсотку тих учасників, які не проходять тест ЗНО з фрізики та математики. Крім цього, збільшується відсоток робіт, які виконані дуже добре, т.б. понад 190 балів, але водночас середній бал не має чітких позитивних чи негативних тенденцій з фрізики чи математики.

Важливими і тривожними є показники відсотку учасників 3НО, що не проходять тестування з фрізики і математики. Так, останні 3 роки є найгіршими як для математики, так і для фрізики за цим показником, який зріс приблизно в 2 рази.

Виявлено, що учасники ЗНО з фрізики та математики, в останні роки сильніше розшаровуються на дві групи: ті, що знають матеріал дуже добре і на тих, хто його знає погано.

Відповідно з таких даних можна зробити висновок про необхідність посилення уваги до навчання учнів з фрізики і математики у закладах освіти.

\section{Використана література:}

1. Офіційний звіт про проведення зовнішнього незалежного оцінювання знань випускників загальноосвітніх навчальних закладів України в 2008 р.: [Електронний ресурс]. URL : // http://testportal.gov.ua/wp-content/upl oads/2017/01/Report2008.pdf

2. Офіційний звіт про проведення в 2018 році зовнішнього незалежного оцінювання результатів навчання, здобутих на основі повної загальної середньої освіти : [Електронний ресурс]. URL : // http://testportal.gov.ua/wp-content/uploads/2018/08/ZV IT-ZN O_2018-Tom_2.pdf 
3. Офіційний звіт про проведення зовнішнього незалежного оцінювання знань випускників загальноосвітніх навчальних закладів України в 2009 р.: [Електронний ресурc]. URL : // http://testportal.gov.ua/wp-content/uploads/2017/01/Report2009.pdf

4. Офіційний звіт про проведення зовнішнього незалежного оцінювання знань випускників загальноосвітніх навчальних закладів України в 2010 році: [Електронний ресурc]. URL : // http://testportal.gov.ua/wp-content/uploads/2017/01/R eport2010.pdf

5. Офіційний звіт про проведення зовнішнього незалежного оцінювання навчальних досягнень випускників загальноосвітніх навчальних закладів у 2011 р.: [Електронний ресурс]. URL // http://testportal.gov.ua/wp-content/uploads/2017/01/R eport2011.pdf

6. Офіційний звіт про проведення зовнішнього незалежного оцінювання навчальних досягнень випускників загальноосвітніх навчальних закладів у 2012 р. : [Електронний ресурс]. URL : // http://testportal.gov.ua/wp-content/uploads/2017/01/Report2012.pdf

7. Офіційний звіт про проведення зовнішнього незалежного оцінювання навчальних досягнень випускників загальноосвітніх навчальних закладів у 2013 р.: [Електронний pecypc]. URL : // http://testportal.gov.ua/wp-content/uploads/2017/01/Report2013.pdf

8. Офіційний звіт про проведення зовнішнього незалежного оцінювання навчальних досягнень осіб, які виявили бажання вступати до вищих навчальних закладів України в 2014 році : [Електронний pecypc]. URL : //http://testportal.gov.ua/wp-content/uploads/2017/01/R eport2014 Tom 1.pdf

9. Офіційний звіт про проведення в 2016 році зовнішнього незалежного оцінювання результатів навчання, здобутих на основі повної загальної середньої освіти : [Електронний ресурс]. URL : http://testportal.gov.ua/wp-content/uploads/2017/01/ZV IT_ZN O_2016_Tom_2.pdf

10. Офіційний звіт про проведення в 2017 році зовнішнього незалежного оцінювання результатів навчання, здобутих на основі повної загальної середньої освіти: [Електронний ресурс]. URL : http://testportal.gov.ua/wp-content/uploads/2017/08/ZVIT_ZN O_2017_Tom_2.pdf

11. Закон України “Про освіту” : [Електронний ресурc]. URL : // https://zakon.rada.gov.ua/laws/show/2145-19

12. Большой энциклопедический словарь : [Електронний ресурс]. URL : //https://vedu.ru/bigencdic/27054/

13. Философский словарь / под ред. И. Т. Фролова. - 7-е изд., перераб. и доп. - Москва : Республика, 2001. - 719 с.

14. Булах І. С. , Войтенко Л. П., Антоненко Ю. П. Моніторинг якості медичної освіти. міжнародний досвід. Медична освіта. 2018. № 3. С. 5-12.

15. Вікторов В.Г. Управління якістю освіти (соціально-філософ. аналіз): монографія. Дніпропетровськ : Пороги, 2005. 286 с.

16. Логинова Л. Г. Методология управления качеством дополнительного образования детей. Москва : АПКиППРО, 2005. $132 \mathrm{c}$

17. Лукіна Т. О. Моніторинг якості освіти : теорія і практика. Київ : Вид. дім “Шкільний світ"; Вид. Л. Галіцина, 2006. 138 с.

18. Поташник М. М. Управление качеством образования / М. М. Поташник. - Москва: Пед. о-во России, 2000. $441 \mathrm{c.}$

19. Якість освіти : [Електронний ресурc]. UR L: // https://mon.gov.ua/ua/tag/yakist-osviti

20. ЗНО в Україні (історична довідка): [Електронний ресурс]. - URL : //http://www.euroosvita.net/ prog/print.php/prog/print.php?id=1128\&-id=4392

21. Освітня агенція міста Києва статистика ЗНО-2016 : [Електронний ресурc]. URL: //https://zno2016. monitoring.in.ua/stats_regions/greater_190/3/

22. Освітня агенція міста Києва статистика ЗНО-2016 : [Електронний ресурс]. URL: //https://zno2016. monitoring.in.ua/stats_regions/not_passed/3/

\section{References:}

[1] Ofitsiinyi zvit pro provedennia zovnishnoho nezalezhnoho otsiniuvannia znan vypusknykiv zahalnoosvitnikh navchalnykh zakladiv Ukrainy v 2008 r. : [Elektronnyi resurs]. URL : //http://testportal.gov.ua/wp-content/uploads/2017/01/R eport2008.pdf

[2] Ofitsiinyi zvit pro provedennia v 2018 rotsi zovnishnoho nezalezhnoho otsiniuvannia rezultativ navchannia, zdobutykh na osnovi povnoi zahalnoi serednoi osvity : [Elektronnyi resurs]. URL : //http://testportal.gov.ua/wp-content/uploads/2018/08/ZV IT-ZNO_2018-Tom_2.pdf

[3] Ofitsiinyi zvit pro provedennia zovnishnoho nezalezhnoho otsiniuvannia znan vypusknykiv zahalnoosvitnikh navchalnykh zakladiv Ukrainy v 2009 r. : [Elektronnyi resurs]. URL : //http://testportal.gov.ua/wp-content/upl oads/2017/01/R eport2009.pdf 
[4] Ofitsiinyi zvit pro provedennia zovnishnoho nezalezhnoho otsiniuvannia znan vypusknykiv zahalnoosvitnikh navchalnykh zakladiv Ukrainy v 2010 rotsi: [Elektronnyi resurs]. URL : //http://testportal.gov.ua/wp-content/uploads/2017/01/R eport2010.pdf

[5] Ofitsiinyi zvit pro provedennia zovnishnoho nezalezhnoho otsiniuvannia navchalnykh dosiahnen vypusknykiv zahalnoosvitnikh navchalnykh zakladiv u $2011 \mathrm{r}$ : : [Elektronnyi resurs]. URL //http://testportal.gov.ua/wp-content/uploads/2017/01/R eport2011.pdf

[6] Ofitsiinyi zvit pro provedennia zovnishnoho nezalezhnoho otsiniuvannia navchalnykh dosiahnen vypusknykiv zahalnoosvitnikh navchalnykh zakladiv u $2012 \mathrm{r}$.: [Elektronnyi resurs]. URL : //http://testportal.gov.ua/wp-content/uploads/2017/01/R eport2012.pdf

[7] Ofitsiinyi zvit pro provedennia zovnishnoho nezalezhnoho otsiniuvannia navchalnykh dosiahnen vypusknykiv zahalnoosvitnikh navchalnykh zakladiv u 2013 r.: [Elektronnyi resurs]. URL : //http://testportal.gov.ua/wp-content/uploads/2017/01/R eport2013.pdf

[8] Ofitsiinyi zvit pro provedennia zovnishnoho nezalezhnoho otsiniuvannia navchalnykh dosiahnen osib, yaki vyiavyly bazhannia vstupaty do vyshchykh navchalnykh zakladiv U krainy v 2014 rotsi : [Elektronnyi resurs]. U RL : //http://testportal.gov.ua/wp-content/uploads/2017/01/Report2014_Tom_1.pdf

[9] Ofitsiinyi zvit pro provedennia v 2016 rotsi zovnishnoho nezalezhnohō otsiniuvannia rezultativ navchannia, zdobutykh na osnovi povnoi zahalnoi serednoi osvity: [Elektronnyi resurs]. URL : http://testportal.gov.ua/wp-content/uploads/2017/01/ZV IT_ZNO_2016_Tom_2.pdf

[10] Ofitsiinyi zvit pro provedennia v 2017 rotsi zovnishnoho nezalezhnoho otsiniuvannia rezultativ navchannia, zdobutykh na osnovi povnoi zahalnoi serednoi osvity: [Elektronnyi resurs]. URL : http://testportal.gov.ua/wp-content/uploads/2017/08/ZVIT_ZNO_2017_Tom_2.pdf

[11] Zakon U krainy "Pro osvitu" : [Elektronnyi resurs]. U RL : // https://zakon.radä.gov.ua/laws/show/2145-19

[12] B olshoi эntsyklopedycheskyi slovar : [Elektronnyi resurs]. URL : //https://vedu.ru/bigencdic/27054/

[13] Fylosofskyi slovar / pod red. Y. T. Frolova. - 7-e yzd., pererab. y dop. - M oskva: Respublyka, 2001. - $719 \mathrm{~s}$.

[14] Bulakh I. Y e., V oitenko L.P., A ntonenko Yu.P. (2018). Monitorynh yakosti medychnoi osvity. mizhnarodnyi dosvid. M edychna osvita. № 3. S. 5-12.

[15] Viktorov V.H. (2005). Upravlinnia yakistiu osvity (sotsialno-filosof. analiz) : monohrafiia. Dnipropetrovsk : Porohy, $286 \mathrm{~s}$.

[16] Lohynova L. H. (2005). M etodolohyia upravlenyia kachestvom dopolnytelnoho obrazovanyia detei. Moskva : APK yPPR 0, $132 \mathrm{~s}$.

[17] Lukina T. 0. (2006). M onitorynh yakosti osvity : teoriia i praktyka. Kyiv : Vyd. dim "Shkilnyi svit"; Vyd. L. Halitsyna, $138 \mathrm{~s}$.

[18] Potashnyk M. M. (2000). U pravlenyekachestvomobrazovanyia/M. M. Potashnyk. - M oskva: Ped. o-vo Rossyy, 441 s.

[19] lakist osvity : [Elektronnyi resurs]. URL : // https://mon.gov.ua/ua/tag/yakist-osviti

[20] ZNO v Ukraini (istorychna dovidka): [Elektronnyi resurs]. - URL: //http://www.euroosvita.net/ prog/print.php/prog/print.php?id=1128\&-id=4392

[21] Osvitnia ahentsiia mista Kyieva statystyka ZNO-2016: [Elektronnyi resurs]. URL: //https://zno2016. monitoring.in.ua/stats_regions/greater_190/3/

[22] Osvitnia ahentsiia mista Kyieva statystyka ZNO-2016: [Elektronnyi resurs]. URL: //https://zno2016. monitoring.in.ua/stats_regions/not_passed/3/

Быковский Я. Т. Сравнительный анализ современного состояния образовательных результатов учащихся по физике и математике: 2008-2018 z2.

В данной статье внимание сосредоточено на вопросе оченивания качества образования. Представлен сравнительный анализ современного уровня образовательных результатов учашихся по физике и математике в период с 2008 2. по 2018 2. по результатам внешнего независимого оиенивания (ВНО).

Особое внимание уделяется анализу изменений и корреляиии данных результатов в охвате участников тестирования по физике и математике; динамики среднего балла; проиента участников тестирования, которые сдают тест по физике и математике на 190 и более баллов, а также тех, которые его не проходят.

Сравнительньй анализ данных свидетельствует, что за 10 лет происходит сильная тенденция к уменьшению количества участников тестирования как по физике, так и по математике. Также происходит значительное увеличение процента тех участников, которые 
не проходят тест 3 НО по физике и математике. Кроме этого, увеличивается прочент работ, которые выполнены очень хорошо (более 190 баллов), но в то же время средний балл не имеет четких положительных или отрицательных тенденций по физике или математике. Важными и тревожными являются показатели процента участников ЗНО, которые не проходят тестирование по физике и математике. Так, последние 3 года являются худшими как для математики, так и для физики по этому показателю, который вырос примерно в 2 раза. Обнаружено, что участники ЗНО по физике и математике, в последние годы сильнее расслаиваются на две группь: те, что знают материал очень хорошо, и те, кто его знает плохо. Соответственно из этих данных можно сделать вывод о необходимости усиления внимания к обучению учашихся по физике и математике в учебных заведениях.

Ключевые слова: качество образования, уровень знаний, физика, математика, внешнее независимое оценивание (ВНО), анализ данных.

BYKovSKIY Y. T. Comparative analysis of the modern state of educational results of students in physics and mathematics: 2008-2018.

In this article attention is focused on the issue of estimation of education quality. A comparative analysis of the current level of educational level of students in physics and mathematics in the period from 2008 to 2018 based on the results of external independent evaluation (EIE) is presented.

Particular attention is paid to analysis of the changes and correlation of student results in coverage of external independent evaluation in physics and mathematics; mean score dynamics; the percentage of test participants who make a test on physics and mathematics for 190 or more points, as well as those that do not pass it.

Keywords: quality of education, level of knowledge, physics, mathematics, external independent evaluation (EIE), data analysis.

DOI: https://doi.org/10.31392/NZ-npu-142.2019.05

УДК 378.091.3-051:780.614.331]:17

Буханєеич В. В.

\section{ЗАБЕЗПЕЧЕННЯ ГЕДОНІСТИЧНОГО КОМПОНЕНТА ЯК УМОВА ІНТЕНСИВНОГО НАВЧАННЯ СКРИПАЛЯ-ПОЧАТКІВЦЯ}

У статті розглянуті поняття "гедонізм" як етичне вчення i “гедоністичне начало психіки" як феномен, щу є основою психологічного розвитку людини, прогресуючого від елементарних "приємно - неприсмно" до понять "добро - зло" . Висвітлено умови, при яких з'являсться відчуття задоволення від навчання гри на скрипиі на початковому етапі, а також методи $і$ способи, що допомагають виконати иі умови на практиці. Розглянуто поняття "гедоністичний еталон". Описано умови вироблення ігрових рухів через механізм підкріплення, як один із способів, що забезпечує комфортний психологічний фон $і$ сприяє швидкому та ефективному освоєнню скрипалем-початківцем фізичних навичок. Розглянуто способи забезпечення психологічного відчуття успішності навчальних дій через пластичне оцінювання, сугестію, фіксацію результатів та констатацію учнем свого музичного зростання. Описано умови, щуо надають можливість забезпечити сочіальне схвалення результатів навчання скрипаля-початківия. Висвітлено чинники, що забезпечують активізацію потреби в навчанні гри на скрипці.

Більшого ефекту в навчанні можна досягти, підсилюючи ті елементи поведінки, які 